\title{
Significance of raised plasma concentrations of tissue-type plasminogen activator and plasminogen activator inhibitor in patients at risk from ischaemic heart disease
}

\author{
David de Bono
}

\begin{abstract}
"That sounds like paradox, Sir. I don't like paradox"-An Ideal Husband, Oscar Wilde
\end{abstract}

Tissue-type plasminogen activator ( $t-P A)$ is a familiar thrombolytic agent for myocardial infarction. It is perhaps natural, therefore, to think of endogenous t-PA as a "good thing" in terms of protection against coronary thrombosis or other consequences of atheroma. This view is supported by studies that showed a correlation between high concentrations of plasminogen activator inhibitor (PAI-1) and increased coronary risk. ${ }^{12}$ At first sight, however, it is more difficult to reconcile with other studies, ${ }^{3-5}$ such as that by Ridker et $a l,{ }^{5}$ which show an equally convincing correlation between cardiovascular risk and increased concentrations of immunologically assayed t-PA.

\section{High t-PA antigen concentrations usually mean low t-PA activity}

The apparent paradox is to some extent resolved by consideration of the relation between t-PA and PAI-1 concentrations and t-PA activity. t-PA forms a stochiometric 1:1 molecular complex with PAI-1 that is inactive and is cleared from the circulation, probably by interacting with hepatic receptors. In population studies, there is an approximately linear relation between $\mathrm{t}-\mathrm{PA}$ and PAI-1 plasma concentrations; the equilibrium of the reaction is such that high t-PA (and higher PAI-1) antigen concentrations are associated with low t-PA activity and vice versa. Thus, to a first approximation, high plasma t-PA antigen concentration is a marker for high PAI-1 concentrations and low intrinsic thrombolytic activity. This has now been shown in several studies in patients with ischaemic heart disease $^{6-8}$ and diabetes. ${ }^{9}$ One of the most meticulous of these studies, at least from the point of haemostatic risk factors, was the ECAT (European concerted action on thrombosis and disabilities) study that examined these risk factors in 3000 patients undergoing coronary angiography for angina pectoris. Patients with one or more coronary stenoses had higher plasma PAI antigen and PAI activity levels, higher t-PA antigen before (but not after) venous occlusion, and longer euglobulin clot lysis times. There was a trend towards lower t-PA activity in patients with coronary disease. This finding also accords with the observation of a significant association between low fibrinolytic activity (measured by dilute blood clot lysis time) and long-term incidence of ischaemic heart disease in the Northwick Park Heart Study. ${ }^{10}$

\section{Control of t-PA and PAI-1 production}

Though recognition that high basal t-PA antigen concentrations in plasma are usually associated with low t-PA activities provides at least a partial explanation for the epidemiological studies, there is still much we do not know about the dynamic balance between t-PA and PAI-1 activity and its control.

The ability of vascular tissues to induce fibrinolysis has long been recognised, and both t-PA and its mRNA can be identified in endothelial cell cultures. However, t-PA production by such cultures varies considerably with culture conditions, and possibly also with species. In situ bovine aortic endothelium produces principally $t-P A$ mRNA and very small amounts of PAI-1, PAI-2, and urokinase (u-PA) mRNA. In culture, the same endothelium produces substantial amounts of all these mRNA species. ${ }^{11}$ Basal production of t-PA by cultured human umbilical endothelium is low, though it can be up regulated by various stimuli; whereas cultured endothelial cells tend to produce large quantities of PAI-1. In vitro, cytokines have a considerable effect on endothelial production of plasminogen activator and inhibitors, but at present we have few clues how these regulate the system in vivo. ${ }^{12-14}$ Interestingly, exposure of endothelium to flowing medium enhances t-PA production, ${ }^{15}$ as it also does production of nitric oxide ${ }^{16}$ and inositol triphosphate. ${ }^{17}$ Again, this effect is initially counter-intuitive, as a high-shear environment should help prevent vascular fibrin deposition, but, as discussed below, it may be more relevant to vascular remodelling. The general principle seems to be that healthy endothelium exposed to an adequate blood flow produces $t-P A$.

PAI-1 is largely released from endothelial cells in a latent form, which is, however, readily activated by denaturants. ${ }^{18}$ It readily binds to extracellular matrix produced by endothelial cells but can be released by partial proteolysis. PAI-1 is expressed on the endothelial cell surface and there is evidence for a negative feedback mechanism whereby t-PA induces 
Factors that alter plasma t-PA and PAl-1 concentrations and t-PA activity

\begin{tabular}{llll}
\hline Factor & $t$-PA concentration & $P A l-1$ concentration & $t$-PA activity \\
\hline Acute exercise & $\uparrow$ then $\downarrow$ & $\sim$ & $\uparrow$ then $\downarrow$ \\
Chronic exercise & $\uparrow$ & $\downarrow$ & $\uparrow$ \\
Venous occlusion & $\uparrow$ then $\downarrow$ & $\sim$ & $\uparrow$ then $\downarrow$ \\
Hypertriglyceridaemia & $\uparrow$ & $\uparrow \uparrow$ & $\downarrow$ \\
Diabetes/hyperinsulinism & $\uparrow$ & $\uparrow \uparrow$ & $\downarrow$ \\
Steroids & $\uparrow$ & $\uparrow \uparrow$ & $\downarrow$ \\
Surgery or trauma & $\uparrow$ & $\uparrow \uparrow$ & $\downarrow$ \\
\hline
\end{tabular}

increased endothelial synthesis of PAI-1. PAI-1 gene activation is also stimulated by bacterial lipopolysaccharide and by tumour necrosis factor (TNF alpha). ${ }^{19}$ Besides endothelium, immunoreactive PAI-1 is present in large quantities in platelets. As stored, more than $95 \%$ of this is inactive; but how and when it might become activated is uncertain. ${ }^{2021}$ There is also evidence of production of PAI-1 by hepatocytes and possibly by smooth muscle cells. It seems likely that most circulating t-PA antigen is of endothelial origin, but there is still uncertainty about the relative importance of endothelium, hepatocytes, or platelets as sources of circulating PAI- 1 . The table shows some of the factors believed to control the production of circulating t-PA and PAI-1.

\section{Diurnal and post exercise fluctuation in} t-PA, PAI-1, and fibrinolytic activity

There is an important diurnal variation in plasma fibrinolytic activity, which is low in the early morning and higher later in the day. ${ }^{22}{ }^{23}$ This correlates with the known diurnal variation in the incidence of myocardial infarction, but we do not know whether the link is causative or coincidental. The principal reason for the variation is a fluctuation in plasma PAI-1 concentration ${ }^{2425}$ but the mechanism for this is unclear. Physical exercise, venous occlusion, and stimuli such as deamino $\mathrm{D}$-arginine vasopressin (DDAVP) all increase plasma t-PA antigen concentration, presumably by displacing t-PA from binding sites on or near endothelium. ${ }^{26}$ It has also been suggested that a reduction in hepatic blood flow during exercise reduces hepatic clearance of t-PA, and thus reduces increasing t-PA plasma activity. ${ }^{27}$ The increase in antigen concentration after exercise is usually also accompanied by an increase in plasmin activation as measured by a reduction in dilute plasma clot lysis time. Increased thrombolytic activity may, however, be followed by a period of rebound inhibition of fibrinolysis, with low plasma t-PA and high PAI-1 concentrations. There is some evidence that in individuals with a low risk of coronary events this rebound is absent or less intense.

Fibrinolytic balance and other cardiac risk factors

An important link between the fibrinolytic system and more traditional cardiovascular risk factors is the positive correlation between hypertriglyceridaemia, glucose intolerance/ hyperinsulinaemia, and high plasma PAI-1 concentrations. An association between alimentary hyperlipaemia and impaired fibrinolysis was recognised by Grief as long ago as $1956,,^{28}$ and subsequent studies have emphasised the role of increased PAI-1 activity associated with hypertriglyceridaemia and hyperinsulinaemia. ${ }^{29-32}$ In vitro, very low density lipoproteins (VLDL) enhance PAI-1 production by cultured endothelial cells ${ }^{33}$ and hepatocyte production of PAI-1 can be stimulated with low density lipoprotein or insulin. ${ }^{34-36}$ The caveats mentioned above about extrapolating cell culture results to the clinical situation also apply here.

\section{Vessel wall fibrinolytic system}

It is important to realise that the fibrinolytic balance in plasma does not necessarily reflect the fibrinolytic balance in the blood vessel wall. Underwood and I found high t-PA activity in human coronary endarterectomy specimens consisting largely of proliferating smooth muscle cells. ${ }^{37}$ The source of this t-PA is likely to be the smooth muscle cells themselves and not infiltrating endothelium. ${ }^{38} 39$ Endarterectomy specimens also contain substantial urokinase-type (u-PA) plasminogen activator activity. Independently of their effect on local fibrin deposition, vessel wall plasminogen activators probably play a major part in the remodelling of vessel wall matrix, either by means of plasmin-mediated proteolysis or, more probably, by initiating the activation of a cascade of metalloproteinases. The plasminogen activity in the vessel wall is increased after angioplasty and after experimental saphenous vein grafting (More RS, Underwood MJ, unpublished). The role of PAI-1 and PAI-2 (which is a more effective inhibitor of u-PA) in modulating this process is at present unclear ${ }^{40}$ but is under intense investigation. Considering the relative masses of vascular smooth muscle and endothelium in the whole body, it remains likely that circulating t-PA is largely of endothelial origin, but vessel wall t-PA and urokinase, PAI-1, and PAI-2 may have important roles in determining the progression of local vascular pathology.

\section{Genetic variations in t-PA and PAI-1 expression}

Genetic manipulation of animal models is a helpful way of establishing the biological relevance of potential components of the coagulation system. Transgenic animals which do not express t-PA have deficient clot lysis, but the condition is compatible with a normal lifespan. Mice which express an excess of plasminogen activator inhibitor tend to develop venous occlusions. ${ }^{41} \mathrm{~A}$ few patients have been described with a bleeding diathesis caused by either an absence of PAI- 1 or by production of a functionally deficient variant. ${ }^{42-44}$ Several more subtle genetic variations at the PAI-1 locus are not associated with 
overt haemostatic problems, but may lead to different responses to, for example, hyperlipidaemia. ${ }^{45}$

\section{Clinical significance of t-PA and PAI-1 concentrations}

So what is the present significance of plasma PAI-1 and t-PA antigen measurements for the clinician? Raised concentrations can certainly be accepted as markers of increased risk (as can raised fibrinogen and factor VII concentrations and a prolonged clot lysis time), but the main aim of identifying risk must be to correct it. At present, the only practical ways of doing this are the conventional, though no less valuable, steps of encouraging weight loss, more exercise, and control of hypertriglyceridaemia. Recognition of the close interactions between plasminogen activators/inhibitors and the cytokine system may given us a lead to interactions between coronary events and infections or neoplasia; and an understanding of the vessel wall proteolytic enzyme system may ultimately help us to counter restenosis after angioplasty or vein graft failure. We urgently need more information about the control of PAI-1 and $\mathrm{t}-\mathrm{PA}$ release and clearance in vivo, and the effects on these of commonly used medications: for example, does propranolol increase t-PA activity by reducing hepatic bloodflow? New technologies are making t-PA and PAI-1 measurements easier and more reliable, but one off estimations are unlikely to help the management of the individual patient. A possible exception to this may be thrombolytic therapy, where knowledge of a high PAI-concentration might lead to a larger dose of thrombolytic agent.

1 Hamsten A, Wiman B, Defaire U, Blombaeck $M$ Increased plasma level of a rapid inhibitor of tissue plasin young survivors of myocardial infarction. N Engl f Med 1985;313:1557-63.

2 Hamsten A, Walldius G, Szamosi A, et al. Plasminogen activator inhibitor in plasma: risk factor for recurren myocardial infarction. Lancet 1987; ii:3-9.

3 Jansson JH, Nilsson TK, Olofsson BO. Tissue plasminoen activator and other risk factors as predictors of cardiovascular events in patients with severe of carpectoris. Eur Heart f 1991;12:157-61.

4 Nilsson TK, Olofsson BO, Jansson JH. Predictive value of tissue plasminogen activator mass concentration on long tissue plasminogen activator mass concentration on lon coronary heart disease: a 7 year follow up. Circulation coronary hea

5 Ridker PM, Vaughan DE, Stampfer MJ, Manson JE, Hennekens $\mathrm{CH}$. Endogenous tissue type plasminogen activator and risk ogenous tissue type plasminogen 1993;341:1165-8.

6 Olofsson BO, Dahlen G, Nilsson TK. Evidence fo increased levels of plasminogen activator inhibitor and tissue plasminogen activator in plasma of patients with angiographically verified coronary disease. Eur Heart $f$ 1989;10:77-82.

7 Oseroff A, Krishnamurti T, Hassett A, Tang D, Alving B Plasminogen activator and plasminogen activator nhibitor activities in men with coronary heart disease. f Lab Clin Med 1989;113:88-93.

8 ECAT Angina pectoris study group. ECAT angina pectoris study: baseline associations of haemostatic factor with extent of coronary arteriosclerosis and other coronary risk factors in 3000 patient's with angina pectori undergoing coronary arteriography. Eur Heart $\not$ 1993 14:8-17.

9 Gray RP, Yudkin JS, Patterson DLH. Plasminogen activator inhibitor: a risk factor for myocardial infarction in diabetic subjects. Br Heart $f$ 1993;69:228-32.

10 Meade TW, Ruddock V, Stirling Y, Chakrabarti R, Mille GJ. Fibrinolytic activity, clotting factors and long-term incidence of ischaemic heart disease in the Northwick Park Heart Study, Lancet 1993;342:1076-9.
11 Pringle SW, Samani NJ, de Bono DP. Effect of heaprin on endothelial cell expression of plasminogen activator and inhibitor mRNA [abstract]. Thromb Haemostas 1993;69:609.

12 Loskutoff DJ, Edington TS. Synthesis of fibrinolytic activator and inhibitor by endothelial cells. Proc Nat Acad Sci USA 1977;74:3903-7.

13 van Hinsbergh VWM. Regulation of the synthesis and secretion of plasminogen activators by endothelial cells. Haemostasis 1988;18:307-27.

14 Schleef RR, Bevilacqua MP, Sawdrey M, Gimbrone MA, Loskutoff DJ. Cytokine activation of vascular endothe lium. 7 Biol Chem 1988;263:5797-803.

15 Diamond SL, Eskin SG, McIntire LV. Fluid flow stimulates tissue plasminogen activator production by cultured human endothelial cells. Science 1989;243: $1483-5$

16 Cooke JP, Stamler J, Andon N, Davies PF, McKinley G Loscalzo J. Flow stimulates endothelial cells to release nitrovasodilator that is potentiated by reduced thiol. $A m$ 7 Physiol 1990;259:H804-12.

17 Nollert MU, Eskin SG, McIntire LV. Shear stress ncreases inositol triphosphate levels in human endothelial cells. Biochem Biophys Res Commun 1990;170:281-7.

18 Hekman CM, Loskutoff DJ. Endothelial cells produce latent inhibitor of plasminogen activator that can be activated by denaturants. $\mathcal{F}$ Biol Chem 1985;260: 11581-7.

19 Loskutoff DJ, Sawdey M, Keeton M, Scneiderman J. Regulation of PAI-1 gene expression in vivo. Thromb Haemostas 1993;70:135-7.

20 Nilsson IM, Felding P, Lecander I, Lenner C, Astedt B. Different types of plasminogen activators in plasma and platelets in pregnant women. Br f Haematol 1986;62: platelets

21 Juhan Vague I, Alessi MC, Fossat C, DeClerck PJ, Kruithof EKO. Plasma determination of plasminogen activator inhibitor antigen 1 must be performed on blood collected in antiplatelet anticoagulant mixture. Thromb Haemostas 1987;58:1096-8.

22 Fearnley GR, Balmforth G, Fearnley E. Evidence of a diurnal fibrinolytic rhythm with a simple method of measuring fibrinolysis. Clin Sci 1957;16:645-50.

23 Andreotti F, Davies GJ, Hackett DR, Khan MI, de Bart ACW, Aber VR, Maseri A, Kluft C. Major circadian fluctuations in fibrinolytic factors and possible relevance to time of onset of myocardial infarction, sudden cardiac death and stroke. Am 7 Cardiol 1988;62:635-7.

24 Kluft C, Jie AFH, Rijken DC, Verheijen JH. Daytime fluctuations in blood of tissue-type plasminogen activator ( $\mathrm{t}-\mathrm{PA})$ and its fast acting inhibitor PAI-1. Thrombosis Haemostas 1988;59:329-32.

25 Juhan-Vague I, Alessi MC, Raccah D, Aillaud MF, Billerey M, Ansaldi J, Philip-Joet C, Vague P. Daytime fluctuations of plasminogen activator inhibitor (PAI-1) fluctuations of plasminogen activator inhibitor (PAI-1) Haemostas 1992;67:76-82.

26 Emeis JJ. Mechanisms involved in short term changes in blood levels of t-PA. In: Kluft C, tissue type plasminogen activator (t-PA): physiological and clinical aspects. Baton Rouge, Florida: CRC Press, 1988, pp $21-35$.

27 de Boer A, Kluft C, Kroon JM, Kasper FJ, Schoemake HC, Pruis J, Breimer DD, Soons PA, Emeis JJ, Cohen $\mathrm{AF}$. Liver blood flow as a major determinant of the clearance of recombinant human tissue-type plasminogen activator. Thromb Haemostas 1992;63:83-7.

28 Grieg HBW. Inhibition of fibrinolysis by alimentary lipaemia. Lancet 1956;ii: 16-8.

29 Landin K, Tengborn L, Smith U. Elevated fibrinogen and plasminogen activator 1 (PAI-1) in hypertension are related to metabolic risk factors for cardiovascular disease. F Intern Med 1990;227:273-8.

30 Mehta J, Mehta P, Lawson D, Saldeen T. Plasma tissue plasminogen activator inhibitor levels in coronary artery disease: correlation with age and serum triglyceride concentration. I Am Coll Cardiol 1987;9:263-8.

31 Juhan Vague I, Roul C, Alessi MC, Ardissone JP, Heim $M$, Vague P. Increased plasminogen activator inhibitor activity in non-insulin dependent diabetic patients. activity in non-insulin dependent diabetic patients. 1989;61:370-3.

32 Auwerx J, Bouillon R, Collen D, Geboers J. Tissue type plasminogen activator antigen and plasminogen activator inhibitor in diabetes mellitus. Arteriosclerosis 1988;8: $68-72$

33 Stiko-Rahm A, Wiman B, Hamsten A, Nilsson J Secretion of plasminogen activator inhibitor 1 from cultured human endothelial cells is induced by very low density lipoprotein. Arteriosclerosis 1990;10:1067-73.

34 Latron Y, Alessi MC, Anfosso F, Nalbonne G, Lafont H, Juhan Vague I. Effect of low density lipoproteins on secretion of plasminogen activator inhibitor 1 (PAI-1) by human endothelial cells and hepatoma cells. Fibrinolysis 1990;4(suppl 2):82-3.

35 Kooistra T, Bosma P, Toens H, van den Berg A, Meyer $\mathrm{P}$, Princen $\mathrm{H}$. Plasminogen activator inhibitor 1: Biosynthesis and mRNA levels are increased by insulin in cultured human hepatocytes. Throm Haemostas 1989; 62:723-8.

36 Alessi MC, Juhan Vague I, Kooistra T, Declerck PJ, Collen D. Insulin stimulates the synthesis of plasminoCen activator inhibitor 1 by the human hepatocellular cell line Hep G2. Thromb Haemostas 1988;60:491-4. 
37 Underwood MJ, de Bono DP. Increased fibrinolytic activity in the intima of atheromatous coronary arteries: protection at a price? Cardiovasc Res 1993;27:882-5.

38 Clowes AW, Clowes MM, Au YPT, Reidy MA, Belin D Smooth muscle cells express urokinase during mitogenesis and tissue type plasminogen activator during migration in injured rat carotid artery. Circ Res 1990;67:61-7.

39 Clowes AW, Clowes MM, Kirkman TR, Jackson CL, Au YPT, Kenagy R. Heparin inhibits the expression of tissue type plasminomention the expression of tisin injured rat carotid artery. Circ Res 1992;70:1128-36.

40 Zoellner H, Woyta J, Gallicchio M, McGrath K, Hamilton JA. Cytokine regulation of the synthesis of plasminogen activator inhibitor 2 by human vascula endothelial cells: comparison with plasminogen activator inhibit

41 Erickson LA, Fici GJ, Lund JE, Boyle TP, Polites HG, Marotti KR. Development of venous occlusions in mice transgenic for the plasminogen activator inhibitor 1 gene. Nature 1990;346:74-6.

42 Schleef RR, Higgins DL, Pillemer E, Levitt LJ. Bleeding diathesis due to decreased functional activity of type 1 plasminogen activator inhibitor. $\mathcal{f}$ Clin Invest 1989;83: 1747-52.

43 Dieval J, Nguyen G, Gross S, Delobel J, Kruithof EKO. A lifelong bleeding disorder associated with a deficiency of plasminogen activator inhibitor type 1. Blood 1991; 77:528-32.

44 Fay WP, Shapiro AD, Shih JL, Schleef RR, Ginsburg D. Complete deficiency of plasminogen activator inhibitor type 1 due to a frameshift mutation. New Engl $₹$ Med type 1 due to a fram

45 Dawson S, Hamsten A, Wiman B, Henney A, Humphries $S$. Genetic variation at the plasminogen activator S. Genetic variation at the plasminogen activator
inhibitor-1 locus is associated with altered levels of plasminogen activator inhibitor 1 activity. Arterioscler Throm 1991;11:183-90.

\section{$A$ letter from Europe}

\section{Cardiovascular pathology in Europe: a new school}

ColleAgues-There is growing concern among pathologists with an interest in cardiovascular diseases. Pathology, which deals with all aspects of disease, but particularly with the essential nature, the causes, and the development of abnormal conditions, encompasses both the basic and clinical sciences. The general lack of interest of pathologists in cardiovascular diseases and the current explosion of interest in molecular biology have led to an undesirable drifting apart of basic and clinical sciences in the crucial arena of cardiovascular diseases. Cardiovascular pathologists, who by virtue of their training, could bridge this gap are struggling to keep their identity as specialists. The present situation in Europe is alarming. The European Society of Cardiology by creating working groups has stimulated research in and integration of basic and clinical sciences. Nonetheless, there is excessive overlap and potential rivalry between groups that share similar basic interests. How, from the viewpoint of pathologists, is interest to be divided between the working groups on developmental anatomy and pathology, cellular biology of the heart, pathogenesis of atherosclerosis, thrombosis and platelets, coronary circulation, myocardial function, and so on?

A group of pathologists who are involved in specialist cardiovascular pathology every day have reconsidered cardiovascular pathology in Europe. They discussed the need to bring together those in Europe with a common interest in cardiovascular pathology and reached a consensus to inaugurate a European School for Cardiovascular Pathology.
The main objective of the school is to identify those with an active interest in cardiovascular pathology and to promote mutual education. The school will provide a platform for liaison between cardiovascular pathologists and adult and paediatric cardiologists and cardiac surgeons. It will promote postgraduate teaching in basic science and clinical medicine, promote and provide support in the implementation of multi-centre studies in cardiovascular pathology, and will coordinate quality control studies of aspects of diagnosis in cardiovascular pathology. Its headquarters are in the Academic Medical Centre, Amsterdam, The Netherlands, and I am its first chairperson.

At a meeting, planned for the spring of 1995, in Amsterdam, there will be state of the art lectures, clinical case presentations, poster sessions, and an open forum to discuss the future of the European School for Cardiovascular Pathology.

If you are interested in registering with the European School for Cardiovascular Pathology-there is no registration fee-write to me for further information. I sign this letter on behalf of Prof Robert $\mathrm{H}$ Anderson, Prof Michael J Davies, Dr Patrick J Gallagher, Prof C James Kirkpatrick, and Prof Gaetano Thiene, founders of the European School for Cardiovascular Pathology.

Department of Cardiovascular Pathology,

ANTON E BECKER

1105 AZ Amsterdam-ZO, The Netherlands 